\title{
Current understanding of metal ions in the pathogenesis of Alzheimer's disease
}

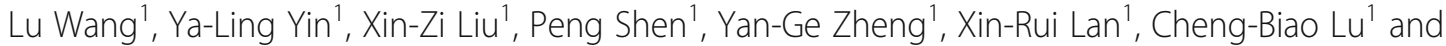 \\ Jian-Zhi Wang ${ }^{2^{*}}$
}

\begin{abstract}
Background: The homeostasis of metal ions, such as iron, copper, zinc and calcium, in the brain is crucial for maintaining normal physiological functions. Studies have shown that imbalance of these metal ions in the brain is closely related to the onset and progression of Alzheimer's disease (AD), the most common neurodegenerative disorder in the elderly.

Main body: Erroneous deposition/distribution of the metal ions in different brain regions induces oxidative stress. The metal ions imbalance and oxidative stress together or independently promote amyloid- $\beta$ (A $\beta$ ) overproduction by activating $\beta$ - or $\gamma$-secretases and inhibiting a-secretase, it also causes tau hyperphosphorylation by activating

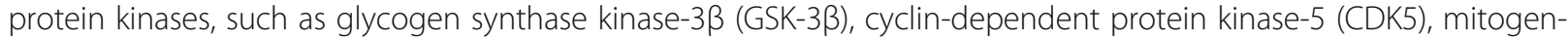
activated protein kinases (MAPKs), etc., and inhibiting protein phosphatase 2A (PP2A). The metal ions imbalances can also directly or indirectly disrupt organelles, causing endoplasmic reticulum (ER) stress; mitochondrial and autophagic dysfunctions, which can cause or aggravate $A \beta$ and tau aggregation/accumulation, and impair synaptic functions. Even worse, the metal ions imbalance-induced alterations can reversely exacerbate metal ions misdistribution and deposition. The vicious cycles between metal ions imbalances and $A \beta /$ tau abnormalities will eventually lead to a chronic neurodegeneration and cognitive deficits, such as seen in AD patients.

Conclusion: The metal ions imbalance induces $A \beta$ and tau pathologies by directly or indirectly affecting multiple cellular/ subcellular pathways, and the disrupted homeostasis can reversely aggravate the abnormalities of metal ions transportation/ deposition. Therefore, adjusting metal balance by supplementing or chelating the metal ions may be potential in ameliorating AD pathologies, which provides new research directions for AD treatment.
\end{abstract}

Keywords: Metal ions, Alzheimer's disease, Amyloid- $\beta$, Tau, Oxidative stress, Autophagy, Synapses

\section{Background}

Alzheimer's disease (AD) is the most common neurodegenerative disorder characterized pathologically by massive extracellular deposition of amyloid- $\beta(A \beta)$ forming senile plaques and intracellular accumulation of the

\footnotetext{
* Correspondence: wangiz@mail.hust.edu.cn

2Department of Pathophysiology, School of Basic Medicine, Key Laboratory of Ministry of Education of China for Neurological Disorders, Tongji Medical College, Huazhong University of Science and Technology, Wuhan 430030, China

Full list of author information is available at the end of the article
}

abnormally modified tau proteins forming neurofibrillary tangles (NFTs) $[1,2]$.

$\mathrm{A} \beta$ is produced from amyloid precursor protein (APP) by cleavage of $\beta$ - and $\gamma$-secretases, in which the $\beta$ secretase cleavage is believed to be the rate-limiting step. In the healthy brains, APP is first cleaved by $\alpha$-secretase to produce an extracellular domain secretory fragment (sAPPa) and a membrane-bound carboxy-terminal fragment. The membrane-bound carboxy-terminal fragment is then cleaved by $\gamma$-secretase into small fragments that can be completely degraded, i.e., the non-amyloid pathway. When APP is processed by the amyloid pathway, it is

(c) The Author(s). 2020 Open Access This article is licensed under a Creative Commons Attribution 4.0 International License, which permits use, sharing, adaptation, distribution and reproduction in any medium or format, as long as you give appropriate credit to the original author(s) and the source, provide a link to the Creative Commons licence, and indicate if changes were made. The images or other third party material in this article are included in the article's Creative Commons licence, unless indicated otherwise in a credit line to the material. If material is not included in the article's Creative Commons licence and your intended use is not permitted by statutory regulation or exceeds the permitted use, you will need to obtain permission directly from the copyright holder. To view a copy of this licence, visit http://creativecommons.org/licenses/by/4.0/ The Creative Commons Public Domain Dedication waiver (http://creativecommons.org/publicdomain/zero/1.0/) applies to the data made available in this article, unless otherwise stated in a credit line to the data. 
cleaved by $\beta$ - and $\gamma$-secretase to produce $A \beta$ of different lengths. Several gene mutations on APP and presenilin (PS1 and PS2, the $\gamma$-secretases) have been identified to promote $A \beta$ production. Furthermore, aggregation of $A \beta$ could form oligomers and plaques, and the oligomers are recognized as the more toxic form of $A \beta[3,4]$.

Tau is a microtubule-associated protein with the normal function in promoting microtubule assembly and maintaining the stability of the microtubules. No gene mutation has been currently detected on tau in AD patients, instead, multiple abnormal posttranslational modifications have been reported to play roles in AD neurodegeneration, such as hyperphosphorylation, SUMOylation, glycosylation, etc. [5-7]. Recent studies suggest that tau hyperphosphorylation may play a dual role in AD neurodegeneration, i.e., tau hyperphosphorylation renders the cells more resistant to acute apoptosis [8-12], while the increasing intracellular tau accumulation induces multiple cellular impairments, including endoplasmic reticulum (ER) stress, deficits of mitophagy and autophagy, deficits of synaptic transmission, etc., and eventually leads to a chronic neurodegeneration [5, 13, 14].

Clinically, $\mathrm{AD}$ is manifested as progressive memory loss, cognitive dysfunction, language disorders, and personality changes. Less than $5 \%$ of the $\mathrm{AD}$ patients is related to dominant gene mutations, including APP and PS1 or PS2. Animal studies suggest that intervention at embryonic stage is beneficial for inducing synaptic plasticity for these pathological gene carriers [15]. The majority AD patients (>95\%) are sporadic onset in which early diagnosis/prediction or intervention of the high-risk factors, such as type 2 diabetes mellitus and hyperhomocysteinemia, may be recommended [16-18]. Ageing is one of the most recognized causes for sporadic AD. As Chinese society is experiencing a fast increase in the elder populations, the number of $\mathrm{AD}$ patients in China is rapidly increasing. Currently, there is no effective drug to cure AD, therefore, understanding the pathological factors that can induce or promote $\mathrm{AD}$ is important.

The homeostasis of metal ions is essential for maintaining normal functions of the brain. In AD patients, changes in the dynamic balance of the metal ions in the brain are closely related to the $A \beta$ deposition and tau hyperphosphorylation/accumulation, suggesting a crucial role of the metal irons in the pathogenesis of $\mathrm{AD}$. As both increase and decrease and as well as mislocalization of the metal ions have been observed in $\mathrm{AD}$, several clinical trials by supplementing or chelating or modulating the metal ions have been carried out in $\mathrm{AD}$ patients [19].

Iron is the most abundant d-block metal in human body. The iron content in the normal brain is around $0.04 \mathrm{mg} / \mathrm{g}$ fresh tissue with the concentration of $720 \mu \mathrm{M}$. In the brain, iron is most abundantly detected in the extrapyramidal system, especially in the basal ganglia region; while the iron content is relatively low in cerebral cortex, and it is the lowest in white matter and medulla oblongata [20-22]. An abnormally elevated brain iron is recognized to be the cause of several neurodegenerative diseases, including $\mathrm{AD}$ in which the iron accumulation induces cell death, termed as "iron death" [23].

Zinc is the second most abundant d-block metal ion after iron in human body, and it is an essential trace metal for the human. The brain concentration of zinc is estimated at $150 \mu \mathrm{M}$, which is $\sim 10$ times higher than that in serum. In the brain, $80 \sim 90 \%$ of zinc is tightly bound with proteins to achieve enzymatic activity or structural stability, and over 2800 potential Zn-binding proteins have been identified by proteome. The rest $10 \sim 20 \%$ of mobile zinc $(\mathrm{mZn})$ are largely stored within synaptic vesicles $(>100 \mu \mathrm{M})$ at glutamatergic nerve terminals and it is synaptically released upon neuronal activity, by which it modulates synaptic transmission and multiple biological functions [24, 25]. Both increased and reduced levels of cytoplasmatic zinc have been implicated in $\mathrm{AD}$, suggesting that the intracellular zinc must be tightly regulated to avoid adverse molecular consequences [26].

The copper concentration in human frontal lobe and cerebellum is in the range of $60 \sim 110 \mu \mathrm{M}$. The highest contents of copper are detected in locus coeruleus and substantia nigra, and copper is also enriched in the hippocampus [27]. Copper is an extremely effective catalyst, which serves as an active component for over 30 enzymes. Complex of copper and $A \beta$ oligomers is able to penetrate the neurons and can trigger oxidative stress within different neuronal sub-compartments. Although copper has been observed to be enriched in the amyloid plaques and NFTs of the AD brains, several copper deficits have also been observed in the AD brains, in which the copper content in cerebral cortex, frontal cortex, amygdala, and hippocampus decreased by up to $50 \%$ compared with the control $[28,29]$.

Calcium is one of the highest metal ions $(\sim 1200 \mathrm{~g})$ in adult human body. The extracellular concentration of $\mathrm{Ca}^{2+}$ is $10^{-3} \mathrm{M}$, which is almost ten-thousand times higher than that of the intracellular $\mathrm{Ca}^{2+}\left(10^{-7} \mathrm{M}\right)$. As a common second messenger, cellular calcium homeostasis plays a pivotal role in regulating many neuronal functions, including neural growth and differentiation, action potential, synaptic plasticity, and learning and memory. In $\mathrm{AD}$ experimental models, the intraneuronal calcium concentration is increased [30], and an elevated calcium level generally appear to be toxic to the cells and it triggers subsequent pathological processes of AD.

In the following section, we review the role of metal ions in the pathogenesis of $\mathrm{AD}$, focusing on the role of 
iron, copper, zinc, and calcium in $A \beta$ and tau pathologies, oxidative stress, autophagic and synaptic deficits.

\section{Main text}

\section{Role of metal ions in AD-like $A \beta$ and tau pathologies}

Erroneous deposition of iron, copper, zinc, or elevation of calcium in different brain regions can promote $A \beta$ overproduction, tau hyperphosphorylation and their aggregation/accumulation. The abnormality of the related metal transporters is a key factor inducing the incorrect distribution of metal ions in the brain.

\section{Iron}

Iron is an essential nutrient but high levels of iron are toxic mainly due to the catalytic generation of destructive hydroxyl radicals. Iron is transferred into the neurons via transferrin (Tf), divalent metal transporter 1 (DMT1), and lactoferrin (Lf), while it is transferred out of neurons by ferroportin (FPN). As a multifunctional iron-binding globular glycoprotein, Lf has high affinity for $\mathrm{Fe}^{3+}$. Iron can be transported to tissues and organs with blood circulation by bounding to Tf. Therefore, the dysregulation of DMT1, Lf, Tf and FPN not only affects the distribution but also accumulation of iron in the brain.

An increased iron level is correlated with the amount of $A \beta$ plaques and tau pathologies, and iron increases $A \beta$ toxicity by impeding the ordered aggregation of $A \beta$ [31]. The binding of iron to $A \beta$ or to tau induces $A \beta$ aggregation and tau hyperphosphorylation, leading to formation of senile plaques and NFTs, and as well as the increased neurotoxicity of $A \beta$ and tau [32, 33]. Iron increases APP translation and $A \beta 42$ production/accumulation in the retina with no observed change in secretase levels or cleavage activities [34]. $\mathrm{Fe}^{2+}$ ions bound to the $\mathrm{N}$-terminal region of $A \beta$, which can modify $A \beta$ and generate oxygen radicals to induce damages on the membrane surface [35]. In a human neuroblastoma cell line (SHSY5Y), elevated $\mathrm{Fe}^{3+}$ can bind to APP mRNA and promote APP translation, and the $\mathrm{Fe}^{3+}$ can activate $\beta$-secretase and thus induces $A \beta$ production [36]. It was also shown that huperzine $A$ could attenuate $A \beta$ and tau pathologies in APP/PS1 mice, while feeding the animals with a high iron diet abolished the protective effect of the huperzine A [37]. The increased iron inhibits $\alpha$-secretase through down-regulating furin [38]. These studies together suggest a detrimental role of iron in $\mathrm{AD}$. Therefore, maintaining iron homeostasis can inhibit APP translation and A $\beta$ overproduction by activating $\alpha$-secretase [39]. On the other hand, it was reported that iron could promote APP translation to attenuate the toxicities of lead $(\mathrm{Pb})$ [40], suggesting a protective role of iron in APP metabolism. In addition to the effects of iron on APP as mentioned above, APP could reversely affect iron, i.e., to stabilize the iron exporter FPN1, and the heavy subunit of the iron-storage protein, ferritin; by which the elevated APP can regulate metabolisms of brain and peripheral iron to attenuate brain iron elevation during aging [41].

$\mathrm{Fe}^{2+}$ can promote tau phosphorylation by activating cyclin-dependent kinases-5 (CDK5) and glycogen synthase

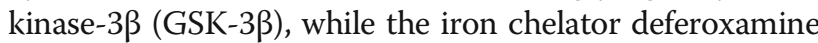
can reduce the degree of iron-induced tau hyperphosphorylation in the mouse brain [42]. Iron-mediated tau hyperphosphorylation may be caused by the activation of extracellular regulated protein kinase1/2 (ERK1/2) and mitogen-activated protein kinase (MAPK) pathway [43, 44]. On the other hand, it was also observed that treatment of the cultured hippocampal neuron with $\mathrm{Fe}^{3+}$ decreases tau phosphorylation, which correlates with a decreased activity of CDK5 [45]. The differences of the experimental systems used in the studies may at least partially contribute to the observed discrepancy. A recent stduy has also shown that tau protein is reqiured to mediate iron export, which can prevent ferroptotic damage after ischemic stroke [46].

\section{Copper}

In $\mathrm{AD}$ patients, an increased copper depositing has been detected and it can interact with $A \beta$ and tau proteins to promote the pathological aggregation and deposition of $\mathrm{A} \beta$ and tau proteins.

Copper ions can bind to $A \beta$ and induce oligomer formation, and eventually lead to $\mathrm{A} \beta$ aggregation. $\mathrm{Cu}^{2+}$-stabilized $A \beta 1-42$ interacts with the lipid bilayer and thus increases the permeability of membrane [47]. However, nitration of $\mathrm{A} \beta 1-42$ can dramatically inhibit the $\mathrm{Cu}^{2+}$ induced $A \beta 1-42$ oligomerization and neurotoxicity in vitro [48]. Furthermore, $\mathrm{Cu}^{2+}$ significantly affects the amyloid cascade, by which it interacts with APP through a $\mathrm{Cu}^{2+}$-binding domain [49]. Copper chelator can inhibit the activity of $\beta$-secretase [50]. In a preclinical $\mathrm{AD}$ model, small amounts of copper in drinking water can induce $A \beta$ accumulation and significantly retard the learning ability [51]. Interestingly, it was also reported that the complex formed by $\mathrm{A} \beta$, monoamine neurotransmitters and $\mathrm{Cu}^{2+}$ can mediate $\mathrm{Cu}^{2+}$ translocation, by which it reduces $A \beta$ toxicity [52].

Excess copper can promote tau hyperphosphorylation and the copper chelating agents attenuate tau phosphorylation in human neuroblastoma cells. Suppressed levels of copper in plasma and brain resulted in a marked attenuation of tau phosphorylation in transgenic mouse expressing human tau [53]. The copper-responsive transcription factor, Sp1, can bind to the promoter of tau gene, which also links copper to the transcription of tau [54]. 


\section{Zinc}

Regarding the alterations or role of zinc in $\mathrm{AD}$, large numbers of controversial results have been reported. Some demonstrated that zinc concentration in senile plaques and neuropils of AD increased 2 3-fold compared with the controls, while others showed a decreased zinc concentration in hippocampus or amygdala of $\mathrm{AD}$ patients. The reasons for the discrepancy are not very clear, different experimental systems used for the study could be at least one of them. These evidences strongly suggest that zinc is required for normal neural functions while excessive or misdirected zinc is harmful to the neural cells.

By analyzed 48 independent plaques in the hippocampus, James et al. demonstrated that the areal concentrations $\left(\mathrm{ng} \mathrm{cm}^{-2}\right)$ of iron, copper and zinc were significantly higher in plaques than in the surrounding neutrophils in APP/PS1 mice. Interestingly, only the level of zinc in the plaques remained elevated after adjustment of tissue density [55]. In addition to increasing protein deposition, direct binding of zinc to $A \beta$ also reduces the solubility of $A \beta$ and thus exacerbates damage to neurons by increasing $A \beta$ aggregation [56]. Immediately after addition of $A \beta 1-40$, zinc ions can block the cation channel on the surface of the membrane, but subsequent $A \beta$ fiber formation fragments the membrane that cannot be stopped by zinc [57]. Zinc ions are associated with APP processing, and interference in the hydrolysis of the APP by zinc results in abnormal cleavage of APP and deposition of A $\beta$, possibly owing to the decreased $\alpha$-secretase cleavage of the zinc-bound APP or the increased $A \beta$ production from APP in the presence of zinc. Additionally, a disintegrin and metalloprotease 10 (ADAM10), whose function can be activated by zinc, can also catalyzes the non-amyloidogenic $\alpha$-secretase cleavage of the APP $[58,59]$.

Excessive of zinc also induces tau aggregation and formation of the NFTs. Zinc can directly bind to tau monomers and stimulate the phosphorylation of tau proteins by activate GSK-3 $\beta$, ERK1/2, and c-Jun N-terminal kinase (JNK) $[60,61]$. Zinc also induces protein phosphatase 2A (PP2A) inactivation and tau hyperphosphorylation through Src-dependent pathway, which ultimately leads to a net increase in phosphorylated tau that may exacerbate AD-like tau pathologies. In genetically modified mice with high expression of human tau protein, zinc chelating agent inhibited the activation of Src, thereby reduced the inhibitory phosphorylation of PP2A at Tyr307 with attenuation of tau phosphorylation and aggregation $[62,63]$.

\section{Calcium}

Intracellular $\mathrm{Ca}^{2+}$ dysregulation is an early manifestation of AD. Studies have shown that $\mathrm{Ca}^{2+}$ concentrations near $A \beta$ deposits are significantly increased, and the increase of $\mathrm{Ca}^{2+}$ likely plays a key role in the cognitive deficits associated with $\mathrm{AD}[64,65] . \mathrm{Ca}^{2+}$ elevation can promote $A \beta$ production and the cellular toxicity of $A \beta$, while the elevation of $A \beta$ in turn contributes to the increased intracellular $\mathrm{Ca}^{2+}$. Therefore, a positive feedback loop may exist between $\mathrm{Ca}^{2+}$ and $\mathrm{A} \beta$, which may exacerbate the neurodegeneration and cognitive deficits in $\mathrm{AD}$ patients [66].

$\mathrm{A} \beta$ can promote the opening of voltage-dependent calcium channels, which in turn increases the intracellular concentration of $\mathrm{Ca}^{2+}$ [67]. An increased intracellular $\mathrm{Ca}^{2+}$ concentration can promote the overexpression of $\mathrm{L}$ type calcium channel subtype (Cav1.2) in the hippocampal cell membranes in models of $\mathrm{AD}$, which further promote the influx of $\mathrm{Ca}^{2+}$ [68]. Majority reports suggest that the intracellular calcium overload can promote $\mathrm{A} \beta$ production and aggregation. For instance, the elevated cytoplasmic $\mathrm{Ca}^{2+}$ by inhibiting of sarcoplasmic/endoplasmic reticulum (S/ER) calcium ATPase (SERCA) or liberating $\mathrm{Ca}^{2+}$ release via the ryanodine receptor ( $\mathrm{RyR})$ can robustly activate $\beta$ secretase and thus increase $A \beta$ production [69]. Therefore, inhibition of $\mathrm{Ca}^{2+}$ influx can reduce the neurotoxicity of $A \beta$ oligomers, levels of insoluble $A \beta 1-40$ and $A \beta 1-42$ in the hippocampus of $\mathrm{AD}$ transgenic mice [70]. Studies also demonstrated that $\mathrm{Ca}^{2+}$ ions actively participate in $\mathrm{A} \beta$ promoted membrane damage, i.e., $\mathrm{Ca}^{2+}$ ions inhibit $\mathrm{A} \beta$ mediated membrane poration but enhance membrane fragmentation by lipid loss due to fiber growth on the membrane surface [71].

Given that many kinases can be activated by $\mathrm{Ca}^{2+}$, dysregulation of $\mathrm{Ca}^{2+}$ homeostasis, such as seen during ER stress, can increase tau phosphorylation [14, 72, 73]. Conversely, intracellular tau accumulating can also induce ER stress and cause $\mathrm{Ca}^{2+}$ overload, the latter induces dephosphorylation of $\mathrm{Ca}^{2+}$-calmodulin-dependent protein kinase IV (CaMKIV) and cAMP-responsive element binding protein (CREB) by activating calcineurin [5]; the $\mathrm{Ca}^{2+}$ overload can also activate JAK2STAT1 signaling, and the upregulated STAT1 directly binds to the specific GAS elements of N-methyl-D-aspartate receptors (NMDARs) and thus inhibits the transcription of NMDARs [14]; the cleaved tau-induced STAT1 elevation also activates BACE1 to promote $A \beta$ production [74]; all of which reveal new mechanisms underlying tau-induced synapse impairments and cognitive deficits.

\section{Role of metal ions in oxidative stress}

Oxidative stress is a state of cellular damage caused by free radicals because of the insufficient functioning of the antioxidant system [75]. Under physiological conditions, the peroxidation-antioxidant system is in equilibrium. When this balance is disturbed, the body responds to oxidative stress by producing free radicals, including 
reactive oxygen species (ROS), such as $\bullet \mathrm{O}_{2}, \mathrm{H}_{2} \mathrm{O}_{2}$, and $\cdot \mathrm{OH}$, and reactive nitrogen species (RNS), such as - ONOO and $\bullet$ NO.

Neurons in the brain are extremely sensitive to free radicals. DNA damage, protein oxidation, lipid peroxidation, and production of advanced glycosylation end products (AGEs) in the AD brains are usually related to free radical attacks and metal imbalances [76, 77]. Oxidative stress has been wildly detected in AD patients and the animal models, and the imbalance of metal ions, such as iron, copper, zinc, and calcium, can cause oxidative stress, tau hyperphosphorylation, $\mathrm{A} \beta$ deposition, cross-linking of nerve fibers and nerve cell damages, which are closely related to the pathogenesis of AD.

\section{Iron}

The reversible transition of iron from $\mathrm{Fe}^{2+}$ to $\mathrm{Fe}^{3+}$ catalyzes the electron transfer reaction. However, excessive redox reactions can disrupt the transition. The iron content in the brain is tightly regulated. When the concentration of iron in the brain is too high, oxidative stress occurs through the Haber-Weiss and Fenton reaction that directly generates ROS. The overproduction of ROS subsequently causes lipid peroxidation of the neuronal membrane, DNA damage, and neuron impairment in the brain $[78,79]$.

Oxidative stress has been observed in mild cognitive impairment with a correlated elevation of iron in glial cells and cerebellum. The glia act as immune cells in the brain and participate in maintaining homeostasis and multiple brain functions. Though the role of cerebellum in $\mathrm{AD}$ has not been extensively studied, the increased iron and free radical generation had been detected in both glial cells and cerebellum in the early stage of $\mathrm{AD}$ [80], and in cerebellum, loss of Purkinje cells and synaptic alterations in the mossy fibers, granule cell dendrites, parallel fibers and Purkinje cell dendrites with substantial loss of dendritic spines had been shown. High levels of iron were precipitated with $A \beta$ plaques, and the iron can promote toxic $A \beta$ oligomer formation with production of ROS, leading to mitochondrial dysfunction and cell death [81].

\section{Copper}

Copper is a cofactor for $\mathrm{Cu} / \mathrm{Zn}$-superoxide dismutase and plays a key role in scavenging ROS. An imbalanced homeostasis of copper can induce oxidative stress and cause ROS overproduction by Fenton and Haber-Weiss reactions [82]. Interferes with the bidirectional and copper-dependent communication between neurons and astrocytes could eventually lead to various brain diseases.

APP and A $\beta$ have copper binding sites, and their interaction with copper can produce ROS, including $\cdot \mathrm{OH}$, which can cause oxidative damage to $A \beta$ itself and the surrounding proteins and lipids. Moreover, elevated copper reduces the level of GSH, a substrate for enzymes that remove ROS, and enhances the production and cytotoxic effects of ROS [83]. The expression of copperdependent enzymes, such as superoxide dismutase 1 (SOD1) and antioxidant protein 1 (ATOX1), was markedly reduced in multiple microarray studies of AD patients, reinforcing the lack of copper [84]. In addition to the antioxidant role, SOD1 also has anti-inflammatory functions. Therefore, reduced expression of SOD1 can exacerbate ROS accumulation and the chronic neuroinflammation [85].

\section{Zinc}

Although zinc is recognized to be a redox-inert metal ion, there are still evidences showing an active involvement of zinc in redox metabolism. In the brain, metallothionein 3 (MT3) is one of the major players in maintain the homeostasis of zinc, which is chelated as metalthiolate clusters. MT3 regulates zinc in a copper-related manner, and the zinc in MT3 can exchange with copper in the $\mathrm{A} \beta-\mathrm{Cu}$ complex and inhibit the oxidative damage caused by the $\mathrm{A} \beta-\mathrm{Cu}$ complex, $\mathrm{Zn}^{2+}$ can also protect sulfhydryl groups from oxidation in the cells [86]. Therefore, downregulation of zinc or MT3 as observed in the $\mathrm{AD}$ neurons can contribute to the oxidative damages.

Under pathological conditions, excessive zinc is released from presynaptic neurons and astrocytes, which causes NADPH-oxidase activation and ROS production in neurons, and microglial activation, and eventually exacerbates neuronal death [87]. Furthermore, $\mathrm{Zn}^{2+}$ is an inhibitor of many enzymes, therefore, excessive zinc can cause multiple metabolic abnormalities by deregulating related enzyme activities. The mitochondrial respiratory chain is particularly sensitive to $\mathrm{Zn}^{2+}$, and elevated $\mathrm{Zn}^{2+}$ in mitochondria promotes ROS production. Excessive zinc, which can be caused by an increased release from metalloproteins, can induce $A \beta$ production and deposition, and thereby triggering a cascade reaction. Therefore, the oxidative and nitrosative stresses can cause an uncontrolled zinc elevation and $A \beta$ deposition, while zinc and $A \beta$ accumulation can conversely lead to oxidative stress and cytotoxicity, forming a vicious cycle.

\section{Calcium}

Calcium-mediated oxidative stress is largely inseparable from iron. Recent studies show that iron-mediated calcium signaling leads to the downstream activation of a kinase cascade involved in synaptic plasticity. Under physiological conditions, iron-mediated production of ROS promotes a normal calcium-dependent signaling pathway, while excessive iron promotes oxidative stress, leading to an unrestricted increase in calcium signaling that impairs mitochondrial function and other 
downstream targets $[88,89]$. Activation of microglia and astrocytes in the brain of $\mathrm{AD}$ patients can induce ROS and RNS production with dose-dependent increases of glutamate release and calcium entry, leading to neuron death.

\section{Role of metal ions in autophagy}

Autophagy, a highly conservative proteolysis system driven by the lysosome, can remove dysfunctional organelles and misfolded proteins and thus plays an important role in coping with various adverse environmental stresses and maintain cell vitality $[90,91]$. An insufficient autophagy can cause intracellular protein accumulation and thus impair the cellular functions, while excessive autophagy can also destroy the cell microenvironment and cause cell damages. Though both insufficient autophagy and excessive autophagy have been detected in the AD brains, an insufficient autophagy may play a more important role in the accumulation of the misfolded proteins during $\mathrm{AD}$ $[92,93]$, such as tau and $A \beta$ accumulation. Interestingly, a recent study showed that intracellular accumulation of tau proteins could in turn aggravate autophagy deficits by disrupting IST1-regulated ESCRT-III complex formation and autophagosome-autolysosome fusion, which formed a vicious cycle between tau accumulation and autophagy deficit in AD and the related tauopathie [13]. Therefore, autophagy should be a promising therapeutic target for $\mathrm{AD}$, and metal ions change the autophagy processes.

The activity of ubiquitin proteasome system (UPS) is decreased in the AD brains, and the UPS activity is closely intertwined with autophagy functions. Moreover, the copper, Fe and zinc ions can bind to UPS components, e.g., the proteasome and ubiquitin can and thus modify their activity [94].

\section{Iron}

The increased iron accumulation is commonly seen in the brains of $\mathrm{AD}$ patients. Uptake of iron components and lysosomal accumulation of iron-related lipofuscin over time induces autophagy deficits. The iron-rich autolysosomes can produce more ROS that can cause damage to autolysosomal membranes [95]. Ferritin is an intracellular protein that stores iron; therefore, autophagy deficit-related ferritin elevation plays an important role in accumulating iron and mediating the iron toxicities in the AD [96, 97]. Additionally, an increasing iron in the cytoplasm will saturate ferritin and thus prevent ferritin from entering the autolysosome which exacerbates iron accumulation. On the other hand, a rapidly increased iron can activate AMP-activated protein kinase $(\mathrm{AMPK}) /$ mammalian target of rapamycin (mTOR) and promote lysosomal degradation of $A \beta$, which suggests a protective role of a rapidly increased iron in $A \beta$ removal. It is reported that iron exposure in the neonatal period has long-lasting harmful effects on the UPS which can induce memory impairment [98]. The proteasome inhibitor lactacystin causes a marked increase in labile iron and the aggregation of ubiquitin-conjugated proteins prior to cell injury and death in vitro [99].

\section{Copper}

In vitro experiments have shown that excessive addition of copper to the cell culture medium can induce autophagy, and the autophagy here is recognized as a cellular defense mechanism that can reduce cell death [100]. The elevation of copper has been observed in lysosomes, the organelles involved in autophagy [101]. In the redox cycle of metal ions, elevation of copper promotes autophagy and apoptosis of glioma cells by reactive oxygen species and JNK activation [102, 103]. The activity of proteasome can be inhibited by copper at $\mathrm{mM}$ level and copper-chelator complexes can inhibit it [104]. And it is reported $\mathrm{Cu}^{2+}$ ions inhibited interaction of nerve growth factor (NGF)1-14 and ubiquitin [105] .

\section{Zinc}

Zinc plays a role in the regulation of both basal and stress-induced autophagy. When the concentration of $\mathrm{Zn}^{2+}$ is high, the level of autophagy will be increased [106]. Zinc promotes autophagy with the mechanisms involving ERK1/2 activation, which can phosphorylate beclin-1 and thus facilitate the beclin1-PI3K complex formation during autophagic process; zinc can also promote degradation of mTOR, a negative regulator of autophagy, and thus lead to cell autophagy [107]. It was also reported that zinc oxide nanoparticles-induced autophagy may be associated with oxidative stress and the inflammatory process in primary astrocyte cultures [108]. Addition of increasing $\mathrm{Zn}^{2+}$ may interact with specific regions of ubiquitin and promote proteinprotein contacts [109]. And zinc caused UPS impairment resulting in $\alpha$-synuclein aggregation subsequently leading to dopaminergic neurodegeneration [110]. In PC12 cell, zinc-induced autophagosome formation facilitates cell survival [111]. These data suggest that the increased zinc in the $\mathrm{AD}$ brain may be potentially protective in removal of stress-induced abnormal proteins/organelles by autophagy, although the pathological role of the increased zinc in $\mathrm{AD}$-like tau and $\mathrm{A} \beta$ pathologies and protective role of zinc chelator were also reported [112].

\section{Calcium}

In physiological conditions, the extracellular calcium concentration is thousands-fold higher than that of the intracellular calcium. In the face of metabolic pressures, such as hypoxia and nutrient deprivation, transient receptor potential mucolipin 1 (TRPML1) mediates outflow and increases the concentration of $\mathrm{Ca}^{2+}$ in the 
cytoplasm [113]. With increase of intracellular $\mathrm{Ca}^{2+}$, autophagic vesicles is accumulated and autophagy is stimulated, the mechanisms involve $\mathrm{Ca}^{2+} /$ calmodulin-dependent protein kinase kinase $\beta$ (CaMKK $\beta) / A M P K$ activation and mTORC1 inhibition $[114,115]$. Application of BAPTA-AM, a chelator of cytoplasmic $\mathrm{Ca}^{2+}$, can inhibit the accumulation of autophagic vesicles, which confirms the role of $\mathrm{Ca}^{2+}$ in stimulating the autophagy [116].

\section{Role of metal ions in synapses}

Synapse impairment is an early pathological feature of $\mathrm{AD}$, which is positively correlated with cognitive dysfunction in $\mathrm{AD}$ [117]. The homeostasis of metal ions is critical for maintaining synaptic function.

\section{Iron}

Iron is closely related to synaptic functions. It has been reported that the dietary iron is required for synapse formation and iron deficiency reduces synapse formation in the drosophila clock circuit. Iron mediates NMDARdependent stimulation of calcium-induced pathways and hippocampal synaptic plasticity. Non-transferrin-bound iron (NTBI) contributes to the "oxidative tone" which is important for both basal synaptic transmission and longterm potentiation [118]. In the presence of elevated iron, increased synaptic activity can cause iron overload which concurs to the cytotoxic effects, as seen in early stage of $\mathrm{AD}$ patients [119]. On the other hand, long-term excessive iron exposure induces learning and memory deficits in mice with widespread molecular alterations including synapse- and memory-associated proteins [120].

\section{Copper}

Copper is an essential component of neuronal transmission. Upon synaptic depolarization, copper release at micromolar concentrations from copper-containing vesicles into the synaptic cleft modulates synaptic functions [121, 122]. Once released onto the synaptic cleft, copper can act post-synaptically as a high-affinity blocker of NMDAR and glutamatergic a-amino-3-hydroxy-5-methyl-4-isoxazolepropionic acid receptor (AMPAR), thereby producing a marked inhibition of glutamate-mediated neurotransmission [123]. Copper can also control, directly or indirectly, the activity of $\gamma$-aminobutyric acid (GABA) and P2X receptors and thus affect neurotransmission and neuronal excitability. Copper can also modulate synaptic vesicles trafficking and protein interactions, while the neurotransmission can in turn affect copper trafficking and delivery in neuronal cells.

As mentioned above, copper can promote $A \beta$ production and tau hyperphosphorylation. In turn, the aggregating vulnerable proteins, such as APP, prion protein, $\alpha$-synuclein, show copper-binding domains. Therefore, these proteins may act as copper buffers at synapses and participate in the interplay between copper and the neurotransmitters receptors. Mutations of copper pump ATP7A are responsible for disorders with a prominent neurodegenerative component, suggesting that ATP7A may play a pivotal role in the release of copper at synapses. The involvement of copper in synaptic transmission may open new insights for therapeutic interventions of AD.

\section{Zinc}

Among different types of metal ions, zinc is the most extensively studied and recognized one to be involved in regulating synaptic functions. Zinc ion is a potent allosteric inhibitor of NMDA receptors. By its mobile form accounting for $10 \sim 20 \%$ of total zinc, the mZn presents in the excitatory presynaptic vesicles with the concentration $>100 \mu \mathrm{M}$, while the inhibitory neurons have been recognized as no-zinc cells. Excessive intracellular accumulation of $\mathrm{Zn}^{2+}$ induces toxicities through multiple mechanisms, such as increasing ROS production through damaging mitochondrial functions, as often seen after the acute phase of transient ischemia or epilepsy.

Among the three major routes of divalent cation entry, i.e., the NMDA channels, the voltage-sensitive $\mathrm{Ca}^{2+}$ channels (VSCCs), and the $\mathrm{Ca}^{2+}$-permeable AMPA/kainate $(\mathrm{Ca}-\mathrm{A} / \mathrm{K})$ channels, the $\mathrm{Ca}-\mathrm{A} / \mathrm{K}$ channels show the highest permeability to exogenously applied $\mathrm{Zn}^{2+}$. In a model of trans-synaptic $\mathrm{Zn}^{2+}$ movement occurring under conditions of oxygen and glucose deprivation (OGD), it was observed that blockage of NMDAR or VSCC by using MK-801 or $\mathrm{Gd}^{3+}$ increased $\mathrm{Zn}^{2+}$ accumulation, whereas the blocking $\mathrm{Ca}-\mathrm{A} / \mathrm{K}$ channels by using 1-naphthyl acetyl spermine (NAS) or application of the extracellular $\mathrm{Zn}^{2+}$ chelator $\left(\mathrm{Ca}^{2+}\right.$ EDTA) decreased $\mathrm{Zn}^{2+}$ accumulation in the pyramidal neurons of hippocampal CA1 and CA3 subsets. Simultaneously, significant neuron death was shown in the presence of MK-801 and $\mathrm{Gd}^{3+}$, whereas the injury was attenuated by NAS or $\mathrm{Ca}^{2+}$ EDTA. These data suggest a pivotal role of $\mathrm{Ca}-\mathrm{A} / \mathrm{K}$ channel, a route for rapid and direct $\mathrm{Zn}^{2+}$ entry, in zinc accumulation and the neuronal toxicities. Similar to that seen in OGD, downregulation of GluR2 in the dendrites of pyramidal neurons progressively increases the number of $\mathrm{Ca}-\mathrm{A} / \mathrm{K}$ channels with an increased $\mathrm{Zn}^{2+}$ inflow and an increased neuron loss during aging and $\mathrm{AD}$ [124].

Intriguingly, the $\mathrm{Ca}-\mathrm{A} / \mathrm{K}$ channel is highly expressed in hippocampal pyramidal neurons, basal forebrain acetylcholinergic neurons, and the forebrain somatostatin neurons, while these neurons are prominently injured in $\mathrm{AD}$ patients. This evidence imply that proper zinc entry must be protective during $\mathrm{AD}$. The synaptic activity could improve neuronal resistance to apoptosis via 
synaptically released zinc, whereas lowering $\mathrm{Zn}^{2+}$ concentration by using intracellular chelators can cause apoptotic neuronal death [125]. In the central nervous system, the brain-derived neurotrophic factor (BDNF) can modulate critically the neuronal activities, covering from neuronal differentiation and survival to synaptogenesis and activity-dependent synaptic plasticity [126, 127]. The production and maturation of BDNF in the brain is regulated by $\mathrm{Cu}^{2+}$-dependent metalloproteinases. In SHSY5Y cells, $\mathrm{Cu}^{2+}$ treatment decreased proBDNF level in cells and increased pro- and mature BDNF levels in the medium [128] with a strong decrease of the proliferative activity of both cleaved BDNF (1-12) and the full length protein [129]. Application of zinc chelator induced reduction of BDNF level, synaptic plasticity-related proteins and dendritic spine density in vivo, which further confirm that appropriate amount of $\mathrm{Zn}^{2+}$ is essential in brain development and the synaptic functions [130].

At the cellular level, $\mathrm{mZn}$ is loaded onto the presynaptic vesicles by zinc transport protein $\mathrm{ZnT3}$, by which zinc plays a role in modulating neurotransmission and plasticity of glutamatergic neurons. The mice with ZnT3 knock out exhibit learning and memory deficits only at 6 -months but not at 3-months of age. These agedependent cognitive deficits are associated with significantly decreased levels of key hippocampal proteins involved in learning and memory. As aggregation of extracellular $\mathrm{A} \beta$ may trap this synaptic pool of $\mathrm{Zn}^{2+}$, ZnT3 knock out may represent a phenocopy for the synaptic and memory deficits of AD. Interestingly, this $\mathrm{ZnT3}$ deletion mice also showed a reduced synaptic localization of $A \beta$ oligomerization compared to that in wild-type mice [131], which implies a functional role of $\mathrm{A} \beta$ oligomer in the synapses.

\section{Calcium}

In $\mathrm{AD}$, increased levels of $\mathrm{Ca}^{2+}$ in dendrites and dendritic spines have important effects on synaptic dysfunction. Calcineurin is an important enzyme that mediates the signaling pathway of $\mathrm{Ca}^{2+}$ in the central nervous system. Calcineurin can work cooperatively with $A \beta$ or tau and contribute to the loss of dendritic spines and synapses, leading to cognitive deficit in mouse models of $A D$, thus use of calcineurin inhibitors can reverse or improve these impairments $[5,132]$.

Mitochondria are especially abundant in synapses, where they provide energy for calcium homeostasis and synaptic functions. The synaptic mitochondria are more sensitive to calcium overload damage than non-synaptic mitochondria [133]. Cytoplasmic $\mathrm{Ca}^{2+}$ can flow into the mitochondria and activate the calcium-dependent mitochondrial matrix dehydrogenase to produce ATP. However, the cytoplasmic $\mathrm{Ca}^{2+}$ overload causes excessive
$\mathrm{Ca}^{2+}$ influx into the mitochondria. The mitochondrial $\mathrm{Ca}^{2+}$ overload induces ROS overproduction, and thus results in mitochondrial outer membrane permeabilization (MOMP) and the subsequent release of pro-apoptotic factors into the cytoplasm. The pro-apoptotic factors, including cytochrome $\mathrm{C}$ and apoptosis inducing factor, activate caspases that induce apoptosis [134]. During longterm potentiation (LTP), microtubule associated protein 1B (MAP1B) phosphorylation and local concentrations of $\mathrm{Ca}^{2+}$-calmodulin-dependent kinase II (CaMKII) were increased [135]. CaMKII is responsible for phosphorylating MAP2, which enhances synaptic response [136]. The human tau accumulation impairs synapse and memory by activating $\mathrm{Ca}^{2+}$-dependent calcineurin and suppressing nuclear CaMKIV/CREB signaling, which reveals a new mechanism underlying the human tau-induced synaptic toxicity [5].

To help the readers quickly understand the key points, we summarized how metal ions $(\mathrm{Fe}, \mathrm{Cu}, \mathrm{Zn}$ and $\mathrm{Ca}$ ) are involved in AD-like neurodegeneration and memory deficits, mainly from their effects on oxidative stress, $A \beta$ and tau pathologies, autophagic imbalance, and synaptic impairment (Fig. 1).

\section{Conclusions}

The homeostasis of metal ions is critical for the physiological functions of the brain. In AD patients or the animal models, the imbalanced metal ions and their transporters have been widely observed. The deposition of metal ions in different brain regions impairs mitochondrial functions and thus causes oxidative stress, which can result in cascade pathological reactions. By modulating specific protein kinases and/or phosphatases or $\beta-, \gamma-, \alpha$-secretases or inducing oxidative stress, the elevated or imbalanced metal ions can induce or exacerbate $A \beta$ overproduction, tau hyperphosphorylation and $A \beta /$ tau aggregation. Metal ions can also promote or inhibit autophagy by acting on autophagy-related proteins and thus causes autophagy impairments, leading to/or aggravating abnormal intracellular protein accumulation. The synaptic release of certain metal ions is essential for normal synaptic plasticity and the functions, whereas abnormal distribution or metabolism of metal ions induces synaptic dysfunction during the progression of $\mathrm{AD}$, with the mechanisms closely related to the mitochondria in the synapses (Fig. 1).

Although both increase and decrease of the metal ions have been observed in $\mathrm{AD}$, the increased ions accumulation/overload are more commonly seen. Therefore, application of metal ions chelators has been widely studied for ameliorating pathologies and the cognitive functions in AD. An effective metal chelator should have the following features: (i) able to pass through the blood-brain barrier (BBB), (ii) specific for a single metal ion, and (iii) 


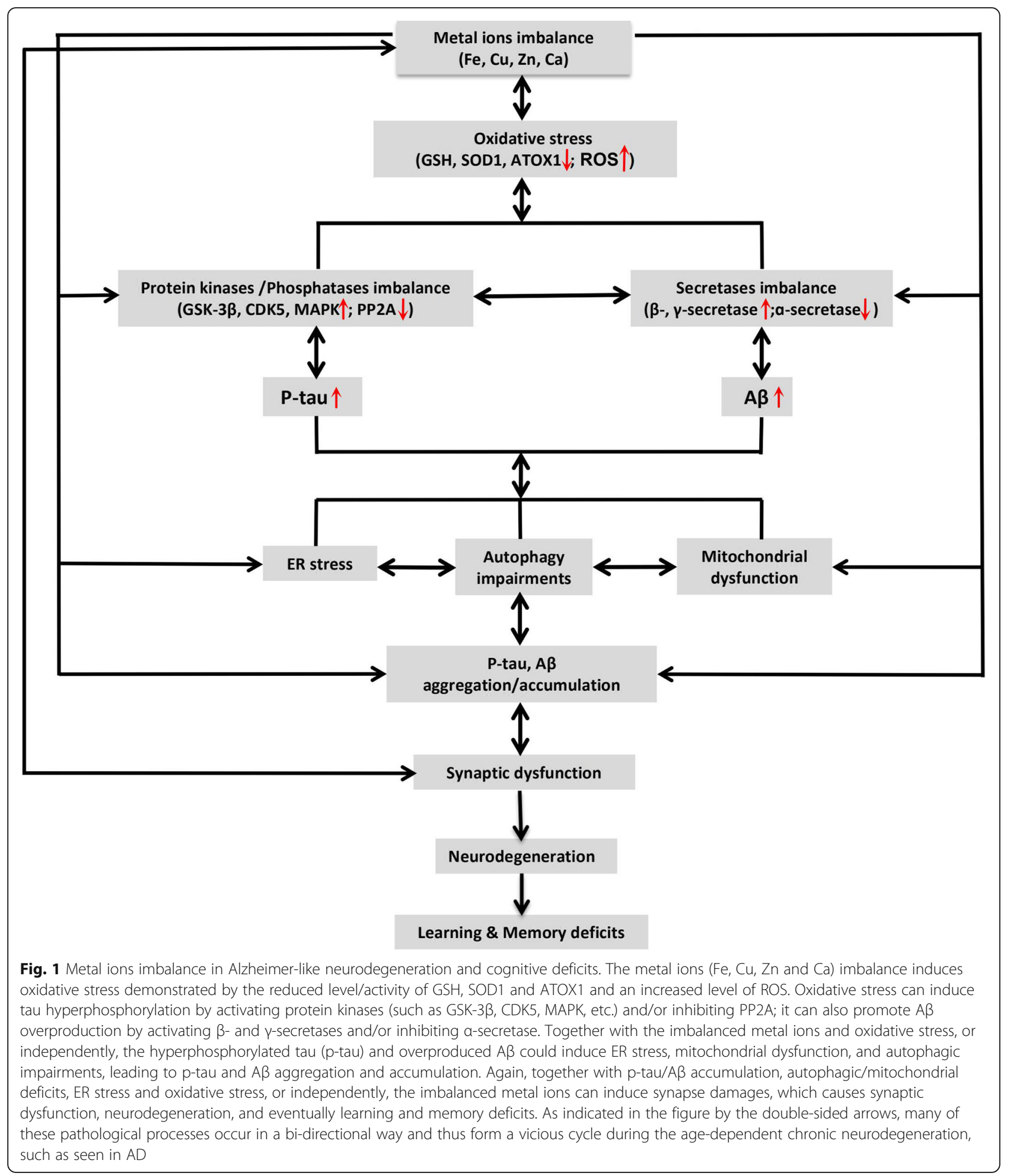

no interference to the normal metabolism of the metal ions. Therapeutic chelators must take into account the necessary coordination to select suitable candidates and the possible success in clinical trials. Therefore, many attempts are made to find metal chelators as drug candidates in recent years, but few chelators have been rationally designed to create safe and effective drugs [137]. As severe deficiency of metal ions has also been observed in the AD brains and it may also contribute to $\mathrm{AD}$ neurodegeneration, therefore, supplement of specific 
metal ions should be considered to these patients. In addition, modulating the cellular localization of the metal ions is also an important approach for developing $\mathrm{AD}$ therapies against metal ions.

Currently, it is still not clear how exactly the concentrations and the distributions of the above-mentioned metal ions are changed during aging and $\mathrm{AD}$. It is also elusive how the brain region-, neural cell-, and suborganelle-specific distribution of the metal ions are normally regulated or maintained in the brain; and how these regulating/maintaining systems are changed during aging and $\mathrm{AD}$. In future studies, more compelling data on these aspects will be meaningful for designing and developing specific interventions.

\section{Abbreviations}

AD: Alzheimer's disease; ADAM: A disintegrin and metalloprotease; AGEs: Advanced glycosylation end products; AMPAR: a-amino-3-hydroxy-5methyl-4-isoxazolepropionic acid receptor; AMPK: AMP-activated protein kinase; A : amyloid- $\beta$; APP: Amyloid precursor protein; ATOX1: Antioxidant Protein 1; BDNF: Neurotrophin brain-derived neurotrophic factor; BBB: Bloodbrain barrier; Ca-A/K: Ca ${ }^{2+}$-permeable AMPA/kainate; CaMK: $\mathrm{Ca}^{2}$-calmodulindependent protein kinase; CaMKKß: $\mathrm{Ca}^{2+} /$ calmodulin-dependent protein kinase kinase $\beta$; CaMKII: $\mathrm{Ca}^{2+}$-calmodulin-dependent kinase II; Cav1.2: L-type calcium channel subtype; CDK5: Cyclin-dependent kinase-5; CREB: CAMPresponsive element binding protein; DMT1: Divalent metal transporter 1; ER: Endoplasmic reticulum; ERK1/2: Extracellular regulated protein kinase 1/2; FPN: Ferroportin; GABA: $\gamma$-aminobutyric acid; GAPDH: Glyceraldehyde-3-

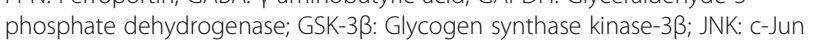
N-terminal kinase; Lf: Lactoferrin; LTP: Long-term potentiation; MAPK: Mitogen-activated protein kinase; MAP1B: Microtubule associatedprotein1B; MOMP: Mitochondrial outer membrane permeabilization; MT3: Metallothionein 3; mTOR: mammalian target of rapamycin; NAS: 1-naphthyl acetyl spermine; NFTs: Neurofibrillary tangles; NGF: Nerve growth factor; NMDAR: N-methyl-D-aspartate receptor; NTBI: Non-transferrin-bound iron; OGD: Oxygen and glucose deprivation; PP2A: Protein phosphatase 2A; PS: Presenilin; RNS: Reactive nitrogen species; ROS: Reactive oxygen species; RyR: ryanodine receptor; SERCA: Sarcoplasmic/ endoplasmic reticulum calcium ATPase; SOD1: Superoxide dismutase 1; Tf: Transferrin; TRPML1: Transient receptor potential mucolipin 1; UPS: ubiquitin proteasome system; VSCCs: Voltage-sensitive $\mathrm{Ca}^{2+}$ channels

\section{Acknowledgements}

Not applicable.

\section{Authors' contributions}

WJZ, WL and LCB conceived and designed the content of the paper. WL, $Y Y L, L X Z$ and SP contributed to literature search. WL, YYL, LXZ, SP, ZYG and LXR wrote the manuscript. WJZ revised the paper and all authors read and approved the manuscript.

\section{Funding}

The study has been supported in parts by Key Science and Technology

Project of Henan (182102310209) and by National Natural Science

Foundation of China (81771517, U1804197).

\section{Availability of data and materials}

Not applicable.

\section{Ethics approval and consent to participate}

Not applicable.

\section{Consent for publication}

Not applicable.

\section{Competing interests}

The authors declare that they have no competing interests.

\section{Author details}

'Key Laboratory of Brain Research of Henan Province, Sino-UK Joint Laboratory of Brain Function and Injury of Henan Province, Department of Physiology and Neurobiology, Xinxiang Medical University, Xinxiang 453003, China. ${ }^{2}$ Department of Pathophysiology, School of Basic Medicine, Key Laboratory of Ministry of Education of China for Neurological Disorders, Tongji Medical College, Huazhong University of Science and Technology, Wuhan 430030, China.

Received: 21 August 2019 Accepted: 11 March 2020

Published online: 03 April 2020

\section{References}

1. Selkoe DJ, Hardy J. The amyloid hypothesis of Alzheimer's disease at 25 years. EMBO Mol Med. 2016;8(6):595-608.

2. Grundke-lqbal I, lqbal K, Tung YC, Wisniewski HM. Alzheimer paired helical filaments: immunochemical identification of polypeptides. Acta Neuropathol. 1984;62(4):259-67.

3. Elmaleh DR, Farlow MR, Conti PS, Tompkins RG, Kundakovic L, Tanzi RE. Developing effective Alzheimer's disease therapies: clinical experience and future directions. J Alzheimers Dis. 2019;71(3):715-32.

4. Dubois B, Hampel H, Feldman HH, Scheltens P, Aisen P, Andrieu S, et al. Preclinical Alzheimer's disease: definition, natural history, and diagnostic criteria. Alzheimers Dement. 2016;12(3):292-323.

5. Yin Y, Gao D, Wang Y, Wang ZH, Wang X, Ye J, et al. Tau accumulation induces synaptic impairment and memory deficit by calcineurin-mediated inactivation of nuclear CaMKIV/CREB signaling. Proc Natl Acad Sci U S A. 2016;113(26):E3773-81.

6. Luo HB, Xia YY, Shu XJ, Liu ZC, Feng Y, Liu XH, et al. SUMOylation at K340 inhibits tau degradation through deregulating its phosphorylation and ubiquitination. Proc Natl Acad Sci U S A. 2014;111(46):16586-91.

7. Wang JZ, Grundke-lqbal I, lqbal K. Glycosylation of microtubule-associated protein tau: an abnormal posttranslational modification in Alzheimer's disease. Nat Med. 1996;2(8):871-5.

8. Wang JZ, Liu F. Microtubule-associated protein tau in development, degeneration and protection of neurons. Prog Neurobiol. 2008;85(2):148-75.

9. Wang JZ, Wang ZH, Tian Q. Tau hyperphosphorylation induces apoptotic escape and triggers neurodegeneration in Alzheimer's disease. Neurosci Bull. 2014;30(2):359-66.

10. Wang JZ, Gao X, Wang ZH. The physiology and pathology of microtubuleassociated protein tau. Essays Biochem. 2014;56:111-23.

11. Wang JZ, Wang ZH. Senescence may mediate conversion of tau phosphorylation-induced apoptotic escape to neurodegeneration. Exp Gerontol. 2015;68:82-6.

12. Yang $Y$, Wang JZ. Nature of tau-associated Neurodegeneration and the molecular mechanisms. J Alzheimers Dis. 2018;62(3):1305-17.

13. Feng Q, Luo Y, Zhang XN, Yang XF, Hong XY, Sun DS, et al. MAPT/tau accumulation represses autophagy flux by disrupting IST1-regulated ESCRTIII complex formation: a vicious cycle in Alzheimer neurodegeneration. Autophagy. 2019;28:1-18.

14. Li XG, Hong XY, Wang YL, Zhang SJ, Zhang JF, Li XC, et al. Tau accumulation triggers STAT1-dependent memory deficits by suppressing NMDA receptor expression. EMBO Rep. 2019;20(6).

15. Liu E, Zhou Q, Xie AJ, Li M, Zhang S, Huang H, et al. Enriched gestation activates the IGF pathway to evoke embryo-adult benefits to prevent Alzheimer's disease. Transl Neurodegener. 2019;8:8.

16. Guo J, Xu C, Ni S, Zhang S, Li Q, Zeng P, et al. Elevation of pS262-tau and Demethylated PP2A in retina occurs earlier than in Hippocampus during Hyperhomocysteinemia. J Alzheimers Dis. 2019;68(1):367-81.

17. Xu ZP, Yang SL, Zhao S, Zheng CH, Li HH, Zhang Y, et al. Biomarkers for early diagnostic of mild cognitive impairment in Type-2 diabetes patients: a multicentre, retrospective, Nested Case-Control Study. EBioMedicine. 2016;5: 105-13.

18. Zhang $Y, X i e ~ J Z, X u X Y, H u ~ J, X u ~ T$, Jin S, et al. Liraglutide ameliorates Hyperhomocysteinemia-induced Alzheimer-like pathology and memory deficits in rats via multi-molecular targeting. Neurosci Bull. 2019;35(4): 724-34.

19. Adlard PA, Bush Al. Metals and Alzheimer's Disease: How Far Have We Come in the Clinic? J Alzheimers Dis. 2018;62(3):1369-79.

20. Drayer B, Burger P, Darwin R, Riederer S, Herfkens R, Johnson GA. MRI of brain iron. AJR Am J Roentgenol. 1986;147(1):103-10. 
21. Moos T, Trinder D, Morgan EH. Cellular distribution of ferric iron, ferritin, transferrin and divalent metal transporter 1 (DMT1) in substantia nigra and basal ganglia of normal and beta2-microglobulin deficient mouse brain. Cell Mol Biol (Noisy-le-Grand). 2000;46(3):549-61.

22. Morris CM, Candy JM, Oakley AE, Bloxham CA, Edwardson JA. Histochemical distribution of non-haem iron in the human brain. Acta Anat. 1992;144(3): 235-57.

23. Levi S, Finazzi D. Neurodegeneration with brain iron accumulation: update on pathogenic mechanisms. Front Pharmacol. 2014;5:99.

24. Paoletti $P$, Vergnano AM, Barbour B, Casado M. Zinc at glutamatergic synapses. Neuroscience. 2009;158(1):126-36.

25. Sensi SL, Paoletti P, Bush Al, Sekler I. Zinc in the physiology and pathology of the CNS. Nat Rev Neurosci. 2009;10(11):780-91.

26. Olesen RH, Hyde TM, Kleinman JE, Smidt K, Rungby J, Larsen A. Obesity and age-related alterations in the gene expression of zinc-transporter proteins in the human brain. Transl Psychiatry. 2016;6(6):e838.

27. Davies KM, Hare DJ, Cottam V, Chen N, Hilgers L, Halliday G, et al. Localization of copper and copper transporters in the human brain. Metallomics. 2013;5(1):43-51.

28. Rembach A, Hare DJ, Lind M, Fowler CJ, Cherny RA, McLean C, et al. Decreased copper in Alzheimer's disease brain is predominantly in the soluble extractable fraction. Int J Alzheimers Dis. 2013;2013:623241.

29. Xu J, Church SJ, Patassini S, Begley P, Waldvogel HJ, Curtis MA, et al. Evidence for widespread, severe brain copper deficiency in Alzheimer's dementia. Metallomics. 2017;9(8):1106-19.

30. Alzheimer's Association Calcium Hypothesis Workgroup. Calcium Hypothesis of Alzheimer's disease and brain aging: A framework for integrating new evidence into a comprehensive theory of pathogenesis. Alzheimers Dement. 2017;13(2):178-82 e17.

31. van Duijn S, Bulk M, van Duinen SG, Nabuurs RJA, van Buchem MA, van der Weerd L, et al. Cortical Iron Reflects Severity of Alzheimer's Disease. J Alzheimers Dis. 2017;60(4):1533-45.

32. Liu B, Moloney A, Meehan S, Morris K, Thomas SE, Serpell LC, et al. Iron promotes the toxicity of amyloid beta peptide by impeding its ordered aggregation. J Biol Chem. 2011;286(6):4248-56.

33. Rogers JT, Xia N, Wong A, Bakshi R, Cahill CM. Targeting the Iron-Response Elements of the mRNAs for the Alzheimer's Amyloid Precursor Protein and Ferritin to Treat Acute Lead and Manganese Neurotoxicity. Int J Mol Sci. 2019;20(4).

34. Guo LY, Alekseev $O$, Li Y, Song Y, Dunaief JL. Iron increases APP translation and amyloid-beta production in the retina. Exp Eye Res. 2014;129:31-7.

35. Wärmländer SKTS, Österlund N, Wallin C, Wu J, Luo J, Tiiman A, et al. Metal binding to the amyloid- $\beta$ peptides in the presence of biomembranes: potential mechanisms of cell toxicity. J Biol Inorg Chem. 2019;24(8):1189-96.

36. Banerjee P, Sahoo A, Anand S, Ganguly A, Righi G, et al. Multiple mechanisms of iron-induced amyloid beta-peptide accumulation in SHSY5Y cells: protective action of negletein. NeuroMolecular Med. 2014;16(4):787-98.

37. Huang XT, Qian ZM, He X, Gong Q, Wu KC, et al. Reducing iron in the brain: a novel pharmacologic mechanism of huperzine $A$ in the treatment of Alzheimer's disease. Neurobiol Aging. 2014;35(5):1045-54.

38. Silvestri $L$, Camaschella C. A potential pathogenetic role of iron in Alzheimer's disease. J Cell Mol Med. 2008;12(5A):1548-50.

39. Bandyopadhyay S, Rogers JT. Alzheimer's disease therapeutics targeted to the control of amyloidprecursor protein translation: maintenance of brain iron homeostasis. Biochem Pharmacol. 2014;88(4):486-94.

40. Rogers JT, Venkataramani V, Washburn C, Liu Y, Tummala V, Jiang H, et al. A role for amyloid precursor protein translation to restore iron homeostasis and ameliorate lead (Pb) neurotoxicity. J Neurochem. 2016;138(3):479-94.

41. Belaidi AA, Gunn AP, Wong BX, Ayton S, Appukuttan AT, Roberts BR, et al. Marked Age-Related Changes in Brain Iron Homeostasis in Amyloid Protein Precursor Knockout Mice. Neurotherapeutics. 2018;15(4):1055-62.

42. Guo C, Wang P, Zhong ML, Wang T, Huang XS, Li JY, et al. Deferoxamine inhibits iron induced hippocampal tau phosphorylation in the Alzheimer transgenic mouse brain. Neurochem Int. 2013;62(2):165-72.

43. Muñoz P, Zavala G, Castillo K, Aguirre P, Hidalgo C, Núñez MT. Effect of iron on the activation of the MAPK/ERK pathway in PC12 neuroblastoma cells. BiolRes. 2006;39(1):189-90.

44. Huang X, Dai J, Huang C, Zhang Q, Bhanot O, Pelle E. Deferoxamine synergistically enhances iron-mediated AP-1 activation: a showcase of the interplay between extracellular-signal-regulated kinase and tyrosine phosphatase. Free Radic Res. 2007;41(10):1135-42.
45. Egaña JT, Zambrano C, Nuñez MT, Gonzalez-Billault C, Maccioni RB. Ironinduced oxidative stress modififies tau phosphorylation patterns in hippocampal cell cultures. Biometals. 2003;16(1):215-23.

46. Tuo QZ, Lei $P$, Jackman KA, Li XL, Xiong H, Li XL, et al. Tau-mediated iron export prevents ferroptotic damage after ischemic stroke. Mol Psychiatry. 2017:22(11):1520-30.

47. Matheou CJ, Younan ND, Viles JH. $\mathrm{Cu}^{2+}$ accentuates distinct misfolding of $A \beta_{(1-40)}$ and $A \beta_{(1-42)}$ peptides, and potentiates membrane disruption. BiochemJ. 2015;466(2):233-42.

48. Zhao J, Gao W, Yang Z, Li H, Gao Z. Nitration of amyloid- $\beta$ peptide (1-42) as a protective mechanism for the amyloid- $\beta$ peptide (1-42) against copper ion toxicity. J Inorg Biochem. 2019;190:15-23.

49. Multhaup G, Schlicksupp A, Hesse L, Beher D, Ruppert T, Masters CL. The amyloid precursor protein of Alzheimer's disease in the reduction of copper (II) to copper(I). Science. 1996;271(5254):1406-9.

50. Wang Z, Zhang $Y H$, Zhang W, Gao HL, Zhong ML, Huang TT, et al. Copper chelators promote nonamyloidogenic processing of ABPP via MT1/2/CREBdependent signaling pathways in ABPP/PS1 transgenic mice. J Pineal Res. 2018;65(3):e12502.

51. Sparks DL, Schreurs BG. Trace amounts of copper in water induce betaamyloid plaques and learning deficits in a rabbit model of Alzheimer's disease. Proc Natl Acad Sci U S A. 2003;100(19):11065-9.

52. Kenche VB, Zawisza I, Masters CL, Bal W, Barnham KJ, Drew SC, et al. Mixed ligand CU2+ complexes of a model therapeutic with Alzheimer's amyloid- $\beta$ peptide and monoamine neurotransmitters. Inorg Chem. 2013;52(8):4303-18.

53. Voss K, Harris C, Ralle M, Duffy M, Murchison C, Quinn JF. Modulation of tau phosphorylation by environmental copper. Transl Neurodegener. 2014;3(1):24.

54. Heicklen-Klein A, Ginzburg I. Tau promoter confers neuronal specificity and binds Sp1 and AP-2. J Neurochem. 2000;75(4):1408.

55. James SA, Churches QI, de Jonge MD, Birchall IE, Streltsov V, McColl G, et al. Iron, copper, and zinc concentration in A $\beta$ plaques in the APP/PS1 mouse model of Alzheimer's disease correlates with metal levels in the surrounding Neuropil. ACS Chem Neurosci. 2017;8(3):629-37.

56. Miller Y, Ma B, Nussinov R. Zinc ions promote Alzheimer Abeta aggregation via population shift of polymorphic states. Proc Natl Acad Sci U S A. 2010; 107(21):9490-5.

57. Sciacca MFM, Kotler SA, Brender JR, Chen J, Lee DK, Ramamoorthy A. Twostep mechanism of membrane disruption by $A \beta$ through membrane fragmentation and pore formation. Biophys J. 2012;103(4):702-10.

58. Seegar TCM, Killingsworth LB, Saha N, Meyer PA, Patra D, Zimmerman B, et al. Structural Basis for Regulated Proteolysis by the a-Secretase ADAM10. Cell. 2017;171(7):1638-48 e7.

59. Malemud CJ. Inhibition of MMPs and ADAM/ADAMTS. Biochem Pharmacol. 2019;165:33-40

60. An WL, Bjorkdahl C, Liu R, Cowburn RF, Winblad B, Pei JJ. Mechanism of zinc-induced phosphorylation of p70 S6 kinase and glycogen synthase kinase 3beta in SH-SY5Y neuroblastoma cells. J Neurochem. 2005;92(5): 1104-15.

61. Kim I, Park EJ, Seo J, Ko SJ, Lee J, Kim CH. Zinc stimulates tau S214 phosphorylation by the activation of Raf/mitogen-activated protein kinasekinase/extracellular signal-regulated kinase pathway. Neuroreport. 2011; 22(16):839-44.

62. Sun $X Y$, Wei YP, Xiong $Y$, Wang $X C$, Xie AJ, Wang $X L$, et al. Synaptic released zinc promotes tau hyperphosphorylation by inhibition of protein phosphatase 2A (PP2A). J Biol Chem. 2012;287(14):11174-82.

63. Xiong $Y$, Jing $X P$, Zhou $X W$, Wang $X L$, Yang $Y$, Sun $X Y$, et al. Zinc induces protein phosphatase $2 \mathrm{~A}$ inactivation and tau hyperphosphorylation through Src dependent PP2A (tyrosine 307) phosphorylation. Neurobiol Aging. 2013; 34(3):745-56.

64. Latulippe J, Lotito D. A mathematical model for the effects of amyloid beta on intracellular calcium. PLoS One. 2018;13(8):e0202503.

65. Kuchibhotla KV, Goldman ST, Lattarulo CR, Wu HY, Hyman BT, Bacskai BJ. Abeta plaques lead to aberrant regulation of calcium homeostasis in vivo resulting in structural and functional disruption of neuronal networks. Neuron. 2008:59(2):214-25.

66. Demuro A, Mina E, Kayed R, Milton SC, Parker I, Glabe CG. Calcium dysregulation and membrane disruption as a ubiquitous neurotoxic mechanism of soluble amyloid oligomers. J Biol Chem. 2005;280(17):17294-300.

67. Ranjan B, Chong KH, Zheng J. Composite mathematical modeling of calcium signaling behind neuronal cell death in Alzheimer's disease. BMC Syst Biol. 2018;12(Suppl 1):10. 
68. Yang L, Wang Z, Wang B, Justice NJ, Zheng H. Amyloid precursor protein regulates Cav1.2 L-type calcium channel levels and function to influence GABAergic short-term plasticity. J Neurosci. 2009;29(50):15660-8.

69. Wang $Y$, Shi $Y$, Wei H. Calcium Dysregulation in Alzheimer's Disease: A Target for New Drug Development. J Alzheimers Dis Parkinsonism. 2017;7(5).

70. Samad N, Ishaq S, Bano S, Manzoor N. Calcium Regulation in Alzheimer's Disease: Mechanistic Understanding. J Coll Physicians Surg Pak. 2017;27(9): 566-71.

71. Sciacca MFM, Monaco I, La Rosa C, Milardi D. The active role of $\mathrm{Ca}^{2+}$ ions in A $\beta$-mediated membrane damage. Chem Commun (Camb). 2018;54(29): 3629-31.

72. Lin L, Cao J, Yang SS, Fu ZQ, Zeng P, Chu J, et al. Endoplasmic reticulum stress induces spatial memory deficits by activating GSK-3. J Cell Mol Med. 2018;22(7):3489-502.

73. Liu ZC, Chu J, Lin L, Song J, Ning LN, Luo HB, et al. SIL1 rescued bip elevation-related tau hyperphosphorylation in ER stress. Mol Neurobiol. 2016;53(2):983-94.

74. Zhang Z, Li XG, Wang ZH, Song M, Yu SP, Kang SS, et al. $\delta$-Secretasecleaved Tau stimulates $A \beta$ production via upregulating STAT1-BACE1 signaling in Alzheimer's disease. Mol Psychiatry. 2018. https://doi.org/10. 1038/s41380-018-0286-z [Epub ahead of print].

75. Samina S. Oxidative Stress and the Central Nervous System. J Pharmacol Exp Ther. 2017;360(1):201-5.

76. Chen Z, Zhong C. Oxidative stress in Alzheimer's disease. Neurosci Bull. 2014;30(2):271-81.

77. García-Blanco A, Baquero M, Vento M, Gil E, Bataller L, Cháfer-Pericás C. Potential oxidative stress biomarkers of mild cognitive impairment due to Alzheimer disease. J Neurol Sci. 2017;373:295-302.

78. Breuer W, Ghoti H, Shattat A, Goldfarb A, Koren A, Levin C, et al. Nontransferrin bound iron in Thalassemia: differential detection of redox active forms in children and older patients. Am J Hematol. 2012;87(1):55-61.

79. Sayre LM, Perry G, Harris PL, Liu Y, Schubert KA, Smith MA. In situ oxidative catalysis by neurofibrillary tangles and senile plaques in Alzheimer' s disease:a central role forbound transition metals. J Neurochem. 2000;74(1): 270-9.

80. Smith MA, Zhu XW, Tabaton M, Liu G, McKeel DW Jr, Cohen ML, et al. Increased iron and free radical generation in preclinical Alzheimer disease and mild cognitive impairment. J Alzheimers Dis. 2010;19(1):363-72.

81. Cheignon C, Tomas M, Bonnefont-Rousselot D, Faller P, Hureau C, Collin F. Oxidative stress and the amyloid beta peptide in Alzheimer's disease. Redox Biol. 2018;14:450-64.

82. Rai RK, Chalana A, Karri R, Das R, Kumar B, et al. Role of hydrogen bonding by Thiones in protecting biomolecules from copper(I)-mediated oxidative damage. Inorg Chem. 2019;58(10):6628-38.

83. Ahuja A, Dev K, Tanwar RS, Selwal KK, Tyagi PK. Copper mediated neurological disorder: visions into amyotrophic lateral sclerosis, Alzheimer and Menkes disease. J Trace Elem Med Biol. 2015;29:11-23.

84. Myhre O, Utkilen H, Duale N, Brunborg G, Hofer T. Metal dyshomeostasis and inflammation in Alzheimer's and Parkinson's diseases: possible impact of environmental exposures. Oxidative Med Cell Longev. 2013;2013:726954.

85. Choo XY, Alukaidey L, White AR, Grubman A. Neuroinflammation and copper in Alzheimer's disease. Int J Alzheimers Dis. 2013;2013:145345.

86. Vašák M, Meloni G. Mammalian metallothionein-3: New functional and structural insights. Int J Mol Sci. 2017;18(6)

87. Furuta T, Ohshima C, Matsumura M, Takebayashi N, Hirota E, Mawaribuchi T, et al. Oxidative stress upregulates zinc uptake activity via Zrt/lrt-like protein 1 (ZIP1) in cultured mouse astrocytes. Life Sci. 2016;151:305-12.

88. Núñez MT, Hidalgo C. Noxious Iron-calcium connections in Neurodegeneration. Front Neurosci. 2019;13:48.

89. Maher P, van Leyen K, Dey PN, Honrath B, Dolga A, Methner A. The role of $\mathrm{Ca} 2+$ in cell death caused by oxidative glutamate toxicity and ferroptosis. Cell Calcium. 2018;70:47-55.

90. Mizushima N, Yoshimori T, Levine B. Methods in mammalian autophagy research. Cell. 2010;140(3):313-26.

91. Klionsky DJ, Abdelmohsen K, Abe A, Abedin MJ, Abeliovich H, Acevedo Arozen A, et al. Guidelines for the use and interpretation of assays for monitoring autophagy. Autophagy. 2016;12(1):1-222.

92. Boland B, Kumar A, Lee S, Platt FM, Wegiel J, Yu WH, et al. Autophagy induction and autophagosome clearance in neurons: relationship to autophagic pathology in Alzheimer's disease. J Neurosci. 2008;28(27):6926-37.
93. Pi H, Li M, Tian L, Yang Z, Yu Z, Zhou Z. Enhancing lysosomal biogenesis and autophagic flux by activating the transcription factor EB protects against cadmium-induced neurotoxicity. Sci Rep. 2017;7:43466.

94. Atrián-Blasco E, Gonzalez P, Santoro A, Alies B, Faller P, Hureau C. Cu and Zn coordination to amyloid peptides: from fascinating chemistryto debated pathological relevance. Coord Chem Rev. 2018;375:38-55.

95. De Biase D, Costagliola A, Pagano TB, Piegari G, Wojcik S, Dziewiątkowski J, et al. Amyloid precursor protein, lipofuscin accumulation and expression of autophagy markers in aged bovine brain. BMC Vet Re. 2017;13(1):102.

96. Belaidi AA, Bush Al. Iron neurochemistry in Alzheimer's disease and Parkinson's disease: targets for therapeutics. J Neurochem. 2016;139(Suppl 1):179-97.

97. Kwiatek-Majkusiak J, Dickson DW, Tacik P, Aoki N, Tomasiuk R, Koziorowski $D$, et al. Relationships between typical histopathological hallmarks and the ferritin in the hippocampus from patients with Alzheimer's disease. Acta Neurobiol Exp (Wars). 2015;75(4):391-8.

98. Figueiredo LS, de Freitas BS, Garcia VA, Dargél VA, Köbe LM, Kist LW, et al. Iron loading selectively increases hippocampal levels of Ubiquitinated proteins and impairs Hippocampus-dependent memory. Mol Neurobiol. 2016;53(9):6228-39.

99. Le W. Role of iron in UPS impairment model of Parkinson's disease. Parkinsonism Relat Disord. 2014;20(Suppl 1):S158-61.

100. Bisceglie F, Alinovi R, Pinelli S, Galetti M, Pioli M, Tarasconi P, et al. Autophagy and apoptosis: studies on the effects of bisthiosemicarbazone copper (ii) complexes on p53 and p53-null tumour cell lines. Metallomics. 2016;8(12):1255-65.

101. Polishchuk EV, Polishchuk RS. The emerging role of lysosomes in copper homeostasis. Metallomics. 2016;8(9):853-62.

102. Sahni S, Bae DH, Jansson PJ, Richardson DR. The mechanistic role of chemically diverse metal ions in the induction of autophagy. Pharmacol Res. 2017;119:118-27.

103. Trejo-Solís C, Jimenez-Farfan D, Rodriguez-Enriquez S, Fernandez-Valverde F, Cruz-Salgado A, Ruiz-Azuara L, et al. Copper compound induces autophagy and apoptosis of glioma cells by reactive oxygen species and JNK activation. BMC Cancer. 2012;12:156.

104. Amici $M$, Forti $K$, Nobili $C$, Lupidi $G$, Angeletti $M$, Fioretti $E$, et al. Effect of neurotoxic metal ions on the proteolytic activities of the $20 \mathrm{~S}$ proteasome from bovine brain. J Biol InorgChem. 2002;7(7-8):750-6.

105. Lanza V, Travaglia A, Malgieri G, Fattorusso R, Grasso G, Di Natale G, et al. Ubiquitin associates with the N-terminal domain of nerve growth factor: the role of copper (II) ions. Chemistry. 2016;22(49):17767-75.

106. Zhao L, Liu Q, Ma S, Zhang Y, Liang P. TPEN attenuates neural autophagy induced by Synaptically-released zinc translocation and improves histological outcomes after traumatic brain injury in rats. Ann Clin Lab Sci. 2018:48(4):446-52

107. Roy R, Singh SK, Chauhan LK, Das M, Tripathi A, Dwivedi PD. Zinc oxide nanoparticles induce apoptosis by enhancement of autophagy via PI3K/Akt/ mTOR inhibition. Toxicol Lett. 2014;227(1):29-40.

108. Song WJ, Jeong MS, Choi DM, Kim KN, Wie MB. Zinc Oxide Nanoparticles Induce Autophagy and Apoptosis via Oxidative Injury and Pro-Inflammatory Cytokines in Primary Astrocyte Cultures. Nanomaterials (Basel). 2019;9(7)

109. Arena G, Fattorusso R, Grasso G, Grasso Gl, Isernia C, Malgieri G, et al. Zinc (II) complexes of ubiquitin: speciation, Affinity and Binding Features. Chemistry. 2011;17(41):11596-603.

110. Kumar V, Singh D, Singh BK, Singh S, Mittra N, Jha RR, et al. Alpha-synuclein aggregation, ubiquitin proteasome system impairment, and L-Dopa response in zinc-induced parkinsonism: resemblance to sporadicParkinson's disease. Mol Cell Biochem. 2018;444(1-2):149-60.

111. Hung $H H$, Huang WP, Pan CY. Dopamine- and zinc-induced autophagosome formation facilitates PC12 cell survival. Cell Biol Toxicol. 2013:29(6):415-29

112. Portbury SD, Hare DJ, Sgambelloni C, Perronnes K, Portbury AJ, Finkelstein DI, et al. Trehalose improves cognition in the transgenic Tg2576 mouse model of Alzheimer's disease. J Alzheimers Dis. 2017;60(2):549-60.

113. Medina DL, Di Paola S, Peluso I, Armani A, De Stefani D, Venditti R, et al. Forrester, Lysosomal calcium signalling regulates autophagy through calcineurin and TFEB. Nat Cell Biol. 2015;17(3):288-99.

114. Zhang L, Fang Y, Cheng X, Lian Y, XU H, Zeng Z, et al. TRPML1 participates in the progression of Alzheimer's disease by regulating the PPAR $/$ /AMPK Mtor Signalling pathway. Cell Physiol Biochem. 2017;43(6):2446-56. 
115. Woods A, Dickerson K, Heath R, Hong SP, Momcilovic M, Johnstone SR, et al. Ca2+/calmodulin-dependent protein kinase kinase-beta acts upstream of AMP-activated protein kinase in mammalian cells. Cell Metab. 2005;2(1): 21-33.

116. Jin Y, Bai Y, Ni H, Qiang L, Ye L, Shan Y, et al. Activation of autophagy through calcium-dependent AMPK/mTOR and PKCO pathway causes activation of rat hepatic stellate cells under hypoxic stress. FEBS Lett. 2016; 590(5):672-82.

117. Chang RY, Nouwens AS, Dodd PR, Etheridge N. The synaptic proteome in Alzheimer's disease. Alzheimers Dement. 2013;9(5):499-511.

118. Rudisill SS, Martin BR, Mankowski KM, Tessier CR. Iron deficiency reduces synapse formation in the Drosophila clock circuit. Biol Trace Elem Res. 2019; 189(1):241-50

119. Altamura S, Muckenthale MU. Iron toxicity in diseases of aging: Alzheimer's disease, Parkinson's disease and atherosclerosis. J Alzheimers Dis. 2009;16(4): 879-95.

120. Wang X, Zhang J, Zhou L, Xu B, Ren X, He K, et al. Long-term iron exposure causes widespread molecular alterations associated with memory impairment in mice. Food Chem Toxicol. 2019;130:242-52.

121. Hung YH, Bush Al, Cherny RA. Copper in the brain and Alzheimer's disease. J Biol Inorg Chem. 2010;15(1):61-76.

122. Kardos J, Kovacs I, Hajos F, Kalman M, Simonyi M. Nerve endings from rat brain tissue release copper upon depolarization. A possible role in regulating neuronal excitability. Neurosci Lett. 1989;103(2):139-44.

123. Dodani SC, Firl A, Chan J, Nam Cl, Aron AT, Onak CS, et al. Copper is an endogenous modulator of neural circuit spontaneous activity. Proc Natl Acad Sci U S A. 2014;111(46):16280-5.

124. Yin HZ, Sensi SL, Ogoshi F, Weiss JH. Blockade of Ca2+-permeable AMPA/ kainate channels decreases oxygen-glucose deprivation-induced Zn2+ accumulation and neuronal loss in hippocampal pyramidal neurons. J Neurosci. 2002;22(4):1273-9.

125. Qiu M, Shentu YP, Zeng J, Wang XC, Yan X, Zhou XW, et al. Zinc mediates the neuronal activity- dependent anti-apoptotic effect. PLoS One. 2017; 12(8):e0182150.

126. Leal G, Afonso PM, Salazar IL, Duarte CB. Regulation of hippocampal synaptic plasticity by brain-derived neurotrophic factor BDNF. Brain Res. 2015:1621:82-101.

127. Zagrebelsky M, Korte M. Form follows function: BDNF and its involvement in sculpting the function and structure of synapses. Neuropharmacology. 2014;76 Pt C:628-38.

128. Hwang JJ, Park MH, Koh JY. Copper activates TrkB in cortical neurons in a metalloproteinase-dependent manner. J Neurosci Res. 2007;85(10):2160-6.

129. Travaglia A, La Mendola D, Magrì A, Nicoletti VG, Pietropaolo A, et al. Copper, BDNF and Its N-terminal Domain: Inorganic Features and Biological Perspectives. Chemistry. 2012;18(49):15618-31.

130. Frazzini V, Granzotto A, Bomba M, Massetti N, Castelli V, d'Aurora M, et al. The pharmacological perturbation of brain zinc impairs BDNF-related signaling and the cognitive performances of young mice. Sci Rep. 2018;8(1):976.

131. Adlard PA, Parncutt JM, Finkelstein DI, Bush Al. Cognitive loss in ZincTransporter-3 Knock-out mice: a Phenocopy for the synaptic and memory, deficits of Alzheimer's disease? J Neurosci. 2010;30(5):1631-6.

132. Cavallucci V, Berretta N, Nobili A, Nisticò R, Mercuri NB, D'Amelio M. Calcineurin inhibition rescues early synaptic plasticity deficits in a mouse model of Alzheimer's disease. NeuroMolecular Med. 2013;15(3):541-8.

133. Brown MR, Sullivan PG, Geddes JW. Synaptic mitochondria are more susceptible to Ca2+overload than nonsynaptic mitochondria. J Biol Chem. 2006;281(17):11658-68

134. Goldstein JC, Waterhouse NJ, Juin P, Evan Gl, Green DR. The coordinate release of cytochrome $\mathrm{c}$ during apoptosis is rapid, complete and kinetically invariant. Nat Cell Biol. 2000;2(3):156-62.

135. Zervas M, Opitz T, Edelmann W, Wanier B, Kucherlapati R, Stanton PK. Impaired hippocampal long-term potentiation in microtubule-associated protein 1B-deficient mice. J Neurosci Res. 2005;82(1):83-92.

136. Fukunaga K, Muller D, Miyamoto E. CaM kinase II in long-term potentiation. Neurochem Int. 1996;28(4):343-58.

137. Liu Y, Nguyen M, Robert A, Meunier B. Metal ions in Alzheimer's disease: a key role or not? Acc ChemRes. 2019;52(7):2026-35.

Ready to submit your research? Choose BMC and benefit from:

- fast, convenient online submission

- thorough peer review by experienced researchers in your field

- rapid publication on acceptance

- support for research data, including large and complex data types

- gold Open Access which fosters wider collaboration and increased citations

- maximum visibility for your research: over $100 \mathrm{M}$ website views per year

At $\mathrm{BMC}$, research is always in progress.

Learn more biomedcentral.com/submissions 